\title{
A Response to Eugene and Kiyo's Dialogue-Disagreement on Dialogic Pedagogy
}

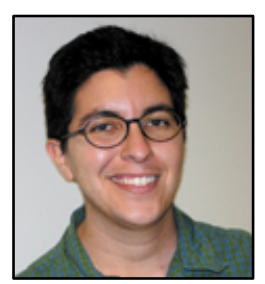

Beth Ferholt

Brooklyn College, City University of New York, USA

\begin{abstract}
Thank you for asking me to respond to the text that you have created, Eugene and Kiyo. I will write about the "freedom from," which Eugene raises and which Kiyo addresses at the end of the text. Kiyo points out that when the teacher's primary active engagement with the learner is to respect the learner's freedom from, then 'engaging with others actively to facilitate their learning and the development of their agency' (pedagogy itself) is hindering the development of self-generated authorship (or making people responsive).
\end{abstract}

I am most interested not in the above argument against prioritizing freedom from in dialogic pedagogy, but in Kiyo's very last sentences. His whole last paragraph reads:

Still, I cannot accept your request to the teacher that the teacher should do nothing to the learner in the lesson except to show respect for the learner's "freedom from." Such a request denies the dialogic teachers' continual efforts to make the lesson dialogic so that they can help the learners to be dialogic agents in school, which is today, becoming tougher for both teachers and students to engage in rich dialogic experiences. And denial as such will make the situation in schools worse than it is, just allowing schools to become monologic arenas dominated by monologic teachers' voices, and through it the monologic voice of the powers outside of classrooms" (above, p. 43).

(I think I agree with Kiyo, but someone could answer: 'I am fine with throwing out the pedagogy, because I am really talking about dialogue.' Actually, Eugene, what do you answer to that?) These sentences do not make a point about dialogic pedagogy. Instead they are about the 'situation in school' and even the situation 'outside of the classroom.'

It seems to me that a discussion about dialogic pedagogy that is not in dialogue with teachers and students is maybe a discussion for a field with which I am not very familiar, perhaps philosophy? As John Shotter said to me when he introduced me to Bakhtin, and I paraphrase: I am not a donkey - 
meaning, I think, that I am not confined by my field or any field. Still, what I do like about the fields in which I am trained, Communication and Education, is that people in these fields may work from within academia but are obliged to listen hard to people outside of their profession.

I do not mean that what we write about pedagogy should be accessible to teachers and students, although I do think that it should sometimes be so. I mean that I like to think about pedagogy in part because I care about teachers and students. But, equally, I like to think about pedagogy because it is a way for me to think about questions that I care about (for instance, why time and space moved differently for me while I played with children when I was a teacher, and how this shift somehow connected my experience of reading literature with my experience of negotiating politics in the world of adults in my preschool...) without becoming stuck in the "glass bead game" (Hesse, 1969).

I am NOT saying that you, Eugene, are stuck in this game. If anyone is not stuck, it is you! However, even if I do not think that talking about something other than pedagogy is a problem, or even that talking about pedagogy without worrying about the situations in schools is a problem, I do think that asking questions, such as 'what is dialogic pedagogy?', with young children (or older children) and with the people who live their working day with these children (teachers), is very interesting.

From here we can go to a discussion about how to have this discussion across professions and generations. Or we can talk about what freedom from can mean from the point of view of the student. Of course we cannot know this point of view, but anyhow, let us talk about this first and methods second.

I know that Eugene tells me again and again that I am not his student. Well, I am not sure that he gets to decide. First, I will make my case that I am both Eugene and Kiyo's student, but even if I am wrong, my use of the following example may be helpful for this discussion.

Kiyo and Eugene, you have both been in academia longer than I have. I was a preschool teacher for ten years after I left college and during this time I only read and wrote a little bit, although I did spend a lot of time thinking about the things that I was seeing and doing in my classroom. When I first met you both I was a new graduate student, very much unfamiliar with reading and writing in academia and (and this second point is very important) I was not in role. I was feeling very stupid (which had not happened to me much, before). I will always think of you both as mentors/teachers who guided me into the field. I still remember many statements from each of you, and these statements guide me professionally. All this while also thinking of you as my colleagues...

Eugene, this is what you wrote to me when you asked me to join this conversation / debate:

There is no peer pressure and I understand if you are too busy and/or simply not interested in this project, please, do not feel shy to say, "no".

For me it is not a question of peer pressure or being interested. I could, of course, say no. However, my wanting to say yes is connected to my history and current position, as I understand these, in relation to you both. You do not have the ability to give me the power to say no.

I am very interested in students' ability to access freedom from. And I do see how focusing on making a learning environment inviting can apply to a frighteningly horrible, as well as a great, learning environment. But, if we are going to bring in Foucault, there is no freedom from. There is just power as far as you can see in all directions, and all we can do is shift it. 
In any case, how does this power shift? I think this is a question that Buber and children and teachers can help us to think about. I will now shift gears (or genres, or position) to talk about what I have learned from a child, a teacher and Buber concerning this question, and in the process I will describe a bit about how I have learned about what I have learned.

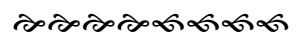

In many of the playworlds that I study, I enter into role intentionally. In one of the playworlds that I recently studied with Monica Nilsson, we filmed a good portion of the playworld but did not intentionally enter into roles. During this playworld I would sit in a corner of the room to film.

Because I speak very little Swedish, as I filmed this playworld I rarely said anything. Because the room was small, I rarely moved from place to place. I would sometimes say something in English to one of the teachers or to Monica, or, very rarely, in response to a child who addressed me.

This playworld was with two and three year old children. Because their play with their teachers was very intense, and very slow, I often kept myself awake during these playworld sessions by thinking of other stories at the same time as I was observing and filming the play narrative. I simultaneously attended to the play and strengthened my attention by making my mind wander. During this experience, I could feel that my features would become very still with my efforts.

After several months of playing in the playworld with me filming, one of the teachers, Tove ${ }^{1}$, told us that one of the children, Maya, had sometimes been standing very still, with her hands still in front of her, looking slightly downward without an expression on her face. Maya was usually silent as she stood in this way, but she intermittently turned to the side and spoke a short bit of gibberish to an imaginary person. Tove told us that she was perplexed and asked Maya's mother if she knew what Maya was doing.

Maya's mother explained that Maya often did this at home. She said that Maya was performing a role and that, when asked, Maya told her mother that she was Beth. Maya was standing very still, concentrating so hard, holding her camera and occasionally speaking "English". We understand this to mean that I had been unintentionally in role in this playworld for a long period of time.

Tove explained my having been in role as myself and unintentionally in this playworld using the concept of a firmament from a quote from Martin Buber: "As long as the firmament of the You is spread over me, the tempests of causality cower at my heels, and the whirl of doom congeals" (1970, p. 59). According to Tove, a firmament was created in this playworld when the first person (a teacher, Isabelle) went into role as the Princess, and this firmament came to cover all who were participants in this playworld. I was a participant in this playworld when I filmed the playworld (for the teachers, as well as for Maya, as the teachers said that they perform differently and often for longer periods of time when I filmed), and this was because of a firmament of a princess.

Monica and I understand what this student and teacher told us about the firmament using J. Aspelin's theory of co-existence (See Ferholt et al., in press and accepted for publication). Aspelin (2011) uses Buber (1970) to present what he calls a two-dimensional conception of education, in which coexistence is opposed to co-operation:

${ }^{1}$ With the exception of the researchers, all participant names have been changed to pseudonyms.

Dialogic Pedagogy: An International Online Journal | http://dpj.pitt.edu

DOI: 10.5195/dpj.2014.125 | Vol. 2 (2014) 
Co-operation represents a process in which individuals coordinate their actions. The process is mediated by social patterns, such as linguistic and paralinguistic rules. Co-operation has an external as well as an internal aspect. On the one hand, it stands for interpersonal communication; on the other, it covers interaction between a subject and his/her surrounding. In the domain of co-operation, people use tools or other means in order to attain different kinds of goals. The activity is defined by some degree of predictability and reticence. Co-operation is created by purposeful action, i.e. it includes goals outside of the relationship.

Co-existence signifies a personal encounter between man and man. The term has ontological meaning, i.e. human essence is assumed to be realized in this event. Co-existence cannot be defined using conventional behavioral concepts. It stands for an existential meeting in which one person is immediately present vis-à-vis another. In the domain of co-existence, no means are used and no medium stands between persons. Co-existence is characterized by unpredictability and it lacks elements of planning and calculation. Coexistence is a goal in itself; i.e. meaning is inherent in the relationship. (p. 10)

What I am arguing is that when we think about freedom from we need to think about the context of this freedom, a context in which the relationship between or around the teacher and children/students and environment may be the pedagogy itself. In other words, I think freedom from may be something that exists only in theoretical spaces (in imagination?). Instead, we should be working from the experience under the firmament, as both our topic and our method. I think that if one looks at dialogic pedagogy from inside dialogic pedagogy (dialogic pedagogy serving as the firmament?), such that one can be in dialogue with teachers and children, then dialogic pedagogy does not appear to depend on freedom from, and this freedom from is not some thing (three headed animal ... ) that is very hard to find, but rather freedom from appears to be a quickly passing transitional state under a firmament which creates and recreates this and other freedoms and restraints.

Let me know if I have missed the point, somehow! I am trying to return to Tsukamoto and Gadamer. I want us to talk about dialogic pedagogy in such a way that we hear something a child/student has to say about this topic and ask ourselves about the horizon of the question. (Embryos of future worldview?)

It also might be both important and useful to ask if we are talking about preschool education/care/raising as well as childhood and older education pedagogy, in this discussion.

Thank you!

Beth

P.S. I would like to add something that I wrote to Ana Marjanovic-Shane in an email exchange, shortly after writing the above: I think freedom from is key but that in early childhood education / educare, at least, there needs to be a 'trapping under the firmament' ... One participates in dialogic pedagogy because one can leave and because there is a community created that makes one not want to leave: I think of the words of Kiyo's retiring teacher to his students!

\section{References}

Aspelin, J. (2011). Co-Existence and Co-Operation: The Two-Dimensional Conception of Education. Education, 1(1), 6-11.

Buber, M. (1970). I and Thou. New York: Charles Scribner's Sons. 


\section{A Response to Eugene's and Kiyo's Dialogue-Disagreement on Dialogic Pedagogy}

Beth Ferholt

Ferholt, B., Nilsson, M., Jansson, A and Alnervik, K. (In press). Creativity in Education:

Play and Exploratory Learning. In Thomas Hansson (Ed.) Contemporary Approaches to Activity Theory. Hershey, Pennsylvania: IGI Global.

Ferholt, B., Nilsson, M., Jansson, A and Alnervik, K. (accepted for publication). Current

Playworld Research in Sweden: Rethinking the Role of Young Children and their Teachers in the Design and Execution of Early Childhood Research. In Will Parnell \& Jeanne Marie lorio (Eds.)

Disrupting through imagination: Rethinking early childhood teacher research. New York:

Routledge, Series: Changing images of early childhood, Series Editor: Dr. Nicola Yelland.

Hesse, H. (1969). The Glass bead game, Magister Ludi. New York: Holt

\section{(c)) EY}

New articles in this journal are licensed under a Creative Commons Attribution 4.0 United States License.

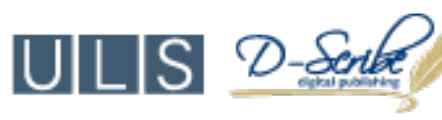

This journal is published by the University Library System, University of Pittsburgh as part of its D-Scribe Digital Publishing Program and is cosponsored by the University of Pittsburgh Press. 